\title{
Water Deficit Stress Mitigation by Foliar Application of Potassium Silicate for Sugar Beet Grown in A Saline Calcareous Soil
}

\author{
A. M. Ali, S. M. Ibrahim and I. A. Abou-Amer \\ Department of Soil Fertility and Microbiology, Desert Research Center, Cairo, Egypt
}

\begin{abstract}
D ROUGHT stress is a serious abiotic factor that limits yield and quality of many crops grown in newly reclaimed lands of Egypt. A field experiment in split-plot design was conducted to assess the usefulness of potassium silicate $\left[\mathrm{K}_{2} \mathrm{SiO}_{3}\right.$ (K-silicate)] on alleviating drought stress on sugar beet grown in a saline calcareous soil. The main plots were assigned for three irrigation intervals as 8, 14 and 20 days, whereas the subplots were assigned for four K-silicate foliar spray concentrations $\left(0,500,1000\right.$ and $2000 \mathrm{mg} \mathrm{L}^{-1}$ silicate). The results indicated that increasing the irrigation interval from 8 to 14 and 20 days caused a significant reduction in sugar beet yield. However, irrigation with interval 14 days and spraying K-silicate at concentrations of $1000 \mathrm{mg} \mathrm{L}^{-1}$ silicate gave root fresh yield of $51.65 \mathrm{Mg} \mathrm{ha}^{-1}$, compared with $38.81 \mathrm{mg} \mathrm{L}^{-1}$ obtained without spraying K-silicate. Likewise, spraying K-silicate in concentration of $1000 \mathrm{mg} \mathrm{L}^{-1}$ silicate increased N, P and K removal in shoot by 66.0, 15.5 and $134.2 \mathrm{~kg} \mathrm{ha}^{-1}$ and in root by $152.0,34.4$ and $244.2 \mathrm{~kg} \mathrm{ha}^{-1}$, respectively. These values were 64.6, 14.2 and $122.6 \mathrm{~kg} \mathrm{ha}^{-1}$ in shoot and 128.4, 29.0 and $223.1 \mathrm{~kg} \mathrm{ha}^{-1}$ in root without spraying $\mathrm{K}$-silicate, respectively. Spraying K-silicate showed also the potential to increase fertilizer use efficiency, and hence can save fertilizers. For instance, increasing irrigation interval to 14 days without spraying K-silicate gave partial factor productivity (PFP) of N, P and K fertilizers to the levels of 647,1252 and $1552 \mathrm{~kg}$ root $\mathrm{kg}^{-1}$ fertilizer, respectively. However, spraying $\mathrm{K}$-silicate at concentration of $1000 \mathrm{mg} \mathrm{L}^{-1}$ silicate increased these values to 861, 1666 and 2066 $\mathrm{kg}$ root $\mathrm{kg}^{-1}$ fertilizer, respectively. In conclusion, this study suggests that spraying K-silicate has the potential to alleviate the negative effects of drought stress on sugar beet yield grown in calcareous soils.
\end{abstract}

Key words: Drought stress, Potassium silicate, Sugar beet, Partial factor productivity

\section{Introduction}

Sugar beet (Beta vulgaris L.) is an important sugar crop in Egypt and the second after sugarcane in the cropped area. Sugar beet is well adapted to a wide range of soil types and considered a tolerate crop to salinity, and mainly cultivated in newly reclaimed lands. Abiotic stresses result from intensive use of natural resources and increasing population contributing significantly to reduce crop yields below the potential maximum yields (Cakmak, 2002 and Ashraf et al., 2010). Drought stress is a major abiotic stress, which has adverse effects on crops. In Egypt, water shortage has become a significant limiting factor for agricultural production in new lands.
Silicon ( $\mathrm{Si}$ ) is abundantly present in soils, but it is not an essential element for plants (Ma \& Takahashi, 2002 and Ashraf et al., 2009). However, importance of Si has been widely recognized for plants under stressful environments (Ma, 2004; Shi et al., 2005; Li et al., 2009; Parveen and Ashraf, 2010). It has been reported that Si treatment could alleviate drought stress (Gong et al., 2005; Hattori et al., 2005), salt stress (Al-Aghabary et al., 2005; Romer-Aranda et al., 2006; Ibrahim et al., 2015), heat stress (Ma, 2004), oxidative damage (Liang et al., 2003 and Zhu et al., 2004). According to Epstein and Bloom (2005), Si does not appear to be beneficial to plants, in most cases, until some stress is imposed. The beneficial role of $\mathrm{Si}$ in alleviating stress in plants exposed to drought is 
mainly due to the enhancement in water relations and photosynthesis (Hattori et al., 2005, Liang et al., 2007 and Maghsoudi et al., 2015).

Water deficit or drought leads to closure of stomatal, reduced transpiration, decrease in water potential of plant tissues, decrease in photosynthesis and ultimately plant growth and development is inhibited (Lawson et al. 2003 and Yordanov et al. 2003). Plants can adapt different mechanisms, morphologically and physiologically, such as drought avoidance and drought tolerance to acclimatize drought stress (Blum, 1996 and Sakamoto \& Murata 2002). Recently, some studies suggested that Si could be used as a growth regulator and it has the potential to improve plant growth under drought stress (Raven, 2003, Trenholm et al., 2004, Gong et al., 2005, Gunes et al. 2007, 2008a, 2008b and Eneji et al., 2008). The ameliorative effect of $\mathrm{Si}$ on drought has been related to several mechanisms such as: depression of excess loss of water by transpiration (Romero-Aranda et al., 2006), osmotic adjustment (Trenholm et al., 2004), improved nutrient uptake (Gunes et al., 2008a) and/or activation of antioxidant defense system in plants (Gunes et al., 2008b). In the present investigation, the usefulness of K-silicate foliar spray has been studied in terms of alleviating water deficit stress on sugar beet grown in a saline calcareous soil.

\section{Materials and Methods}

A field experiment on sugar beet crop was carried out during 2016/2017 growing season in Mariout Research Station of the Desert Research Center at Northwest Nile Delta of Egypt. Soil Samples were collected before initiating the experiment and analyzed for physical and chemical properties (Table 1) following methods described by Page et al. (1982). Available N was extracted by $2 \mathrm{M} \mathrm{KCl}$ solution according to Dahnke and Johnson (1990) and $\mathrm{N}$ in the extract was estimated by Kjeldahl method. Available $\mathrm{P}$ and $\mathrm{K}$ were extracted by $1 \mathrm{M} \mathrm{NH}_{4} \mathrm{HCO}_{3}$ in $0.005 \mathrm{M}$ DTPA adjusted to a pH of 7.6 (Soltanpour, 1991) and then determined using spectrophotometer and flamephotometer, respectively.

The experiment was laid out in a split-plot design with three replications. Main plots were assigned to three irrigation intervals as 8,14 and 20 days, whereas subplots were assigned to four $\mathrm{K}$-silicate $\left(\mathrm{K}_{2} \mathrm{SiO}_{3}\right)$ foliar spray concentrations as $0,500,1000$ and $2000 \mathrm{mg} \mathrm{L}^{-1}$ silicate. Foliar spray with K-silicate treatments were practiced 4 times during the growing season. All treatment plots were received fertilizer recommendations as 60, 31 and $25 \mathrm{~kg} \mathrm{ha}^{-1}$ of N, P and K. Sources of these fertilizers were ammonium nitrate $(33.5 \% \mathrm{~N})$, single superphosphate $\left(15 \% \mathrm{P}_{2} \mathrm{O}_{5}\right)$ and potassium sulphate $\left(48 \% \mathrm{~K}_{2} \mathrm{O}\right)$.

TABLE 1. Some physical and chemical properties of the topsoil layer $(0-30 \mathrm{~cm})$ of the experimental site at Mariout Research Station of the Desert Research Center

\begin{tabular}{lll}
\hline \multicolumn{1}{c}{ Soil characteristics } & Values \\
\hline Texture & Sandy loam \\
Saturation percentage, \% & 35.8 \\
Field capacity, \% & 16.9 \\
Wilting point, \% & 7.0 \\
$\mathrm{pH}^{*}$ & 8.63 \\
$\mathrm{EC}^{* *}, \mathrm{dS} \mathrm{m}{ }^{-1}$ & 8.4 \\
$\mathrm{CaCO}_{3}, \%$ & 21.7 \\
Organic matter, \% & 0.94 \\
Available $\mathrm{N}, \mathrm{mg} \mathrm{kg}^{-1}$ & 68.2 \\
Available $\mathrm{P}, \mathrm{mg} \mathrm{kg}^{-1}$ & 8.1 \\
Available $\mathrm{K}, \mathrm{mg} \mathrm{kg}^{-1}$ & 226 \\
\hline
\end{tabular}

*pH in saturated soil paste. ${ }^{* *}$ Electrical conductivity in saturated soil paste extract.

Egypt. J. Soil. Sci. 59, No. 1 (2019) 
At harvest, 10 plants were taken from each plot. Shoots and roots were cleaned, separated and weighted to determine yield. Shoot and root samples were dried at $70{ }^{\circ} \mathrm{C}$ oven for analysis. Dried samples were ground and digested in $\mathrm{H}_{2} \mathrm{SO}_{4}-\mathrm{H}_{2} \mathrm{O}_{2}$ mixture for $\mathrm{N}, \mathrm{P}$ and $\mathrm{K}$ analysis (Karla, 1997). In the digests, $\mathrm{N}$ was estimated by micro-Kjeldahl method. Phosphorus and $\mathrm{K}$ were determined colorimetrically and flame photometerically, respectively. Sucrose content was determined in fresh root samples using a saccharometer (AOAC, 1995).

The analysis of variance (ANOVA) was performed on different parameters as described by Gomez and Gomez (1984). The difference between means was tested at probability levels 0.05 using Duncan's Multiple Range Test (DMRT). Fertilizer use efficiency in terms of partial factor productivity (PFP) was computed as:

PFP $\left(\mathrm{kg}_{\text {root } \mathrm{kg}^{-1}}\right.$ fertilizer $)=$ root fresh yield in each treatment quantity of nutrient applied

\section{Results and Discussion}

Effect of foliar spray of K-silicate on sugar beet yield and sucrose percentage

Irrigation interval and foliar spray with K-silicate caused significant effects on shoot and root yields of sugar beet (Table 2). In the absence of drought stress (irrigation every 8 days), spraying $\mathrm{K}$-silicate at a concentration of $2000 \mathrm{mg} \mathrm{L}^{-1}$ silicate increased shoot and root fresh yields significantly from 9.8 and $43.13 \mathrm{Mg} \mathrm{ha}^{-1}$ to 12.7 and $54.48 \mathrm{Mg}$ $\mathrm{ha}^{-1}$, respectively. This increase may be due to the presence of $\mathrm{K}$ in the $\mathrm{K}$-silicate solution, which has a significant role in scaling of roots of sugar beet, posing a potential for increasing yield by adjusting $\mathrm{K}$ fertilizer recommendation in the study area. Furthermore, it could be due to reducing the negative effects of high salinity in soil of the experimental site, as noted by Romer-Aranda et al. (2006) and Ibrahim et al. (2015). Increasing the irrigation interval from 8 days to 20 days caused a significant reduction in root yield by around $33 \%$. However, spraying K-silicate significantly alleviated the negative effects of drought on sugar beet yield. Irrigation with interval 14 days and spraying K-silicate at concentrations of 0, 500, 1000 and $2000 \mathrm{mg} \mathrm{L}^{-1}$ silicate gave shoot and root fresh yield values of 8.62 and 38.81, 10.22 and $46.0,11.18$ and 51.65 , and 11.42 and $52.75 \mathrm{Mg}$ $\mathrm{ha}^{-1}$, respectively. On the other hand, increasing the irrigation interval to 20 days with spraying K-silicate at same concentrations gave shoot and root fresh yield values of 6.45 and 28.85 , 7.18 and 32.09, 7.58 and 33.89, and 8.06 and
36.06 $\mathrm{Mg} \mathrm{ha}^{-1}$, respectively. At medium drought stress (irrigation every 14 days), there were no significant differences in shoot and root fresh yield with spraying K-silicate at concentrations of 1000 and $2000 \mathrm{mg} \mathrm{L}^{-1}$ silicate. The inference of this finding suggest that the appropriate concentration of silicate to compensate yield loss due to medium drought stress is $1000 \mathrm{mg} \mathrm{L}^{-1}$.

Sucrose contents in sugar beet root as affected by irrigation interval and foliar spray of K-silicate are shown in Table 2. In general, there were no significant differences in sucrose percentage in all treatments. Nonetheless, having almost same percentages of sucrose with higher root yield with K-silicate foliar application can result in higher quantities of extracted sucrose from sugar beet.

These finding are in line with those of with Eneji et al. (2008) who found that application of $1000 \mathrm{mg} \mathrm{kg}^{-1} \mathrm{~K}$-silicate to the soil of four grass species under deficit irrigation produced the greatest biomass yield responses across species. In fact, $\mathrm{Si}$ has been reported to alleviate drought stress in wide variety of crops (Gao et al., 2004, Hattori et al., 2005), and improve their yields. According to Savant et al. (1999) and Ma (2004), Si reduces the negative effects of drought stress on plants because it gets deposited beneath the cuticle layer of leaves forming a Si-cuticle double layer that increases the rigidity of cell wall and hence reduces water loss through transpiration. Agarie et al. (1998) found that deposition of Si in the cell wall of rice increased internal storage of water and reduced transpiration rate under drought stress.

\section{Effect of foliar spray of $K$-silicate on nutrient removal by sugar beet}

Nutrient removal in shoot and root of sugar beet were significantly influenced by irrigation and K-silicate treatments (Table 3). The highest $\mathrm{N}, \mathrm{P}$ and $\mathrm{K}$ removal was obtained in the presence of K-silicate foliar spray in all irrigation interval treatments. Irrigation every 8 days without spraying K-silicate resulted in N, P and K removal in shoot with values of $60.8,13.4$ and $114.7 \mathrm{~kg}$ ha ${ }^{1}$, respectively. These values in root were 128.8 , 32.3 and $208.9 \mathrm{~kg} \mathrm{ha}^{-1}$, respectively. However, spraying K-silicate in concentration of $1000 \mathrm{mg}$ $\mathrm{L}^{-1}$ silicate increased nutrient removal in shoot to $73.3,16.0$ and $139.7 \mathrm{~kg} \mathrm{ha}^{-1}$ and in root to 155.7 , 35.0 and $252.8 \mathrm{~kg} \mathrm{ha}^{-1}$, respectively. On the other hand, increasing irrigation interval to 14 days without spraying K-silicate resulted in $\mathrm{N}, \mathrm{P}$ and $\mathrm{K}$ removal in shoot with values of 54.9, 11.9 and $103.6 \mathrm{~kg} \mathrm{ha}^{-1}$ and in root with values of 116.0 , 40.8 and $188.3 \mathrm{~kg} \mathrm{ha}^{-1}$, respectively. Inclusion of $\mathrm{K}$-silicate in concentration of $1000 \mathrm{mg} \mathrm{L}^{-1}$ silicate increased nutrient removal in shoot by $66.0,15.5$ and $134.2 \mathrm{~kg} \mathrm{ha}^{-1}$ and in root by 152.0, 34.4 and 
$244.2 \mathrm{~kg} \mathrm{ha}^{-1}$, respectively. Increasing drought stress by irrigation at interval of 20 days without spraying K-silicate decreased N, P and k removal in shoot to values of $37.6,8.0$ and $82.8 \mathrm{~kg} \mathrm{ha}^{-1}$ and in root to values of $86.8,39.0$ and $139.6 \mathrm{~kg}$ $\mathrm{ha}^{-1}$, respectively. However, at same stress level, spraying K-silicate at concentration of $1000 \mathrm{mg}$ $\mathrm{L}^{-1}$ silicate increased nutrient removal in shoot by $44.4,9.5$ and $97.6 \mathrm{~kg} \mathrm{ha}^{-1}$ and in root by 102.0 , 24.3 and $164.0 \mathrm{~kg} \mathrm{ha}^{-1}$, respectively.

Reduced absorption of nutrients can happen due to interference with other nutrients uptake, unloading mechanisms and reduced transpiration (Baligar et al., 2001). Generally, decreasing water availability under drought stress resulted in reduced total mineral uptake and frequently reduced the concentration of nutrients in crop plants (Marschner, 2011). The negative effects of drought on nutrient removal can be due reduced transport of mineral to the root as well as reduced root growth and extension (Samarah et al., 2004). Gunes et al. (2008a) demonstrated that application of Si to sunflower under drought stress has the potential to improve uptake of several nutrients.

Effect of foliar spray of K-silicate on fertilizers PFP of sugar beet

As an indicator of fertilizer use efficiency,
PFP was calculated to show the influence of $\mathrm{K}$-silicate foliar spray on N, P and $\mathrm{K}$ fertilizer use efficiency (Fig. 1-3). In the absence of drought, applying K-silicate in concentration of 1000 $\mathrm{mg} \mathrm{L}^{-1}$ increased PFP for $\mathrm{N}, \mathrm{P}$ and $\mathrm{K}$ fertilizers from 719,1391 and $1725 \mathrm{~kg}$ root $\mathrm{kg}^{-1}$ fertilizer to 869,1681 and $2084 \mathrm{~kg}$ root $\mathrm{kg}^{-1}$ fertilizer, respectively. Increasing irrigation interval to 14 days without spraying K-silicate decreased PFP values to the levels of 647,1252 and $1552 \mathrm{~kg}$ root $\mathrm{kg}^{-1}$ fertilizer, respectively. However, spraying $\mathrm{K}$-silicate at concentration of $1000 \mathrm{mg} \mathrm{L}^{-1}$ silicate increased these values to 861, 1666 and $2066 \mathrm{~kg}$ root $\mathrm{kg}^{-1}$ fertilizer, respectively. Further increase in drought stress by irrigation interval at 20 days substantially decreased PFP without spraying K-silicate to the levels of 481, 931 and $1154 \mathrm{~kg}$ root $\mathrm{kg}^{-1}$ fertilizer, respectively. At same drought level, spraying K-silicate at concentration of 1000 $\mathrm{mg} \mathrm{L}^{-1}$ silicate increased PFP to levels of 565, 1093 and $1356 \mathrm{~kg}$ root $\mathrm{kg}^{-1}$ fertilizer, respectively.

Application of K-silicate seems to enhance N, $\mathrm{P}$ and $\mathrm{K}$ nutrients uptake and offers the potential to improve fertilizer use efficiency in terms of nutrients recovery and yield response, as also reported by Singh et al. (2005). Moreover, root growth increases with K-silicate application, and hence increases the ability of plant to absorb nutrients.

TABLE 2. Effect of irrigation interval and foliar spray of K-silicate on shoot, root yield and sucrose content of sugar beet grown in a calcareous soil

\begin{tabular}{|c|c|c|c|c|c|c|}
\hline \multicolumn{2}{|c|}{ Treatment } & \multirow[b]{2}{*}{$\begin{array}{l}\text { Shoot fresh } \\
\text { yield } \\
\text { Mg ha }^{-1}\end{array}$} & \multirow[b]{2}{*}{$\begin{array}{l}\text { Shoot dry yield } \\
\text { Mg ha- }^{-1}\end{array}$} & \multirow[b]{2}{*}{$\begin{array}{l}\text { Root fresh } \\
\text { yield } \\
\text { Mg ha-1 }^{-1}\end{array}$} & \multirow[b]{2}{*}{$\begin{array}{c}\text { Root dry yield } \\
\text { Mg ha }^{-1}\end{array}$} & \multirow[b]{2}{*}{$\begin{array}{c}\text { Sucrose } \\
\%\end{array}$} \\
\hline $\begin{array}{c}\text { Irrigation } \\
\text { interval(days) }\end{array}$ & $\begin{array}{c}\text { Silicate } \\
\text { concentration } \\
\left(\mathrm{mg} \mathrm{L}^{-1}\right)\end{array}$ & & & & & \\
\hline \multirow{4}{*}{8} & 0 & $9.80 \mathrm{e}$ & $3.24 \mathrm{e}$ & $43.13 \mathrm{~d}$ & $9.00 \mathrm{~d}$ & $17.4 \mathrm{a}$ \\
\hline & 500 & $10.62 \mathrm{~cd}$ & $3.52 \mathrm{~d}$ & $46.72 \mathrm{c}$ & $9.75 \mathrm{~cd}$ & $17.9 \mathrm{a}$ \\
\hline & 1000 & $12.15 \mathrm{a}$ & $3.92 \mathrm{ab}$ & $52.11 \mathrm{ab}$ & $10.87 \mathrm{ab}$ & $17.5 \mathrm{a}$ \\
\hline & 2000 & $12.70 \mathrm{a}$ & $4.10 \mathrm{a}$ & $54.48 \mathrm{a}$ & $11.37 \mathrm{a}$ & $18.0 \mathrm{a}$ \\
\hline \multirow{4}{*}{14} & 0 & $8.62 \mathrm{f}$ & $2.92 \mathrm{f}$ & $38.81 \mathrm{e}$ & $8.10 \mathrm{e}$ & $17.8 \mathrm{a}$ \\
\hline & 500 & $10.22 \mathrm{de}$ & $3.46 \mathrm{~d}$ & $46.00 \mathrm{c}$ & $9.60 \mathrm{~d}$ & $17.6 \mathrm{a}$ \\
\hline & 1000 & $11.18 \mathrm{bc}$ & $3.79 b c$ & $51.65 \mathrm{~b}$ & $10.50 \mathrm{bc}$ & $17.5 \mathrm{a}$ \\
\hline & 2000 & $11.42 \mathrm{~b}$ & $3.72 \mathrm{c}$ & $52.75 \mathrm{ab}$ & $10.65 \mathrm{ab}$ & $17.8 \mathrm{a}$ \\
\hline \multirow{4}{*}{20} & 0 & $6.45 \mathrm{i}$ & $2.08 \mathrm{i}$ & $28.85 \mathrm{~h}$ & $5.96 \mathrm{~g}$ & $18.0 \mathrm{a}$ \\
\hline & 500 & $7.18 \mathrm{~h}$ & $2.27 \mathrm{~h}$ & $32.09 \mathrm{~g}$ & $6.63 \mathrm{fg}$ & $17.6 \mathrm{a}$ \\
\hline & 1000 & $7.58 \mathrm{gh}$ & $2.40 \mathrm{gh}$ & $33.89 \mathrm{fg}$ & $7.00 \mathrm{f}$ & $17.9 \mathrm{a}$ \\
\hline & 2000 & $8.06 \mathrm{fg}$ & $2.55 \mathrm{~g}$ & $36.06 \mathrm{f}$ & $7.45 \mathrm{ef}$ & $18.2 \mathrm{a}$ \\
\hline
\end{tabular}

Means followed by the same letter are not significantly different within the same column at the 0.05 level of probability by Duncan's Multiple Range Test (DMRT).

Egypt. J. Soil. Sci. 59, No. 1 (2019) 
TABLE 3. Effect of irrigation interval and foliar spray of K-silicate on nutrient removal in shoot and root of sugar beet grown in a calcareous soil

\begin{tabular}{|c|c|c|c|c|c|c|c|}
\hline \multicolumn{2}{|c|}{ Treatment } & \multicolumn{3}{|c|}{$\begin{array}{c}\text { Shoot nutrient removal } \\
\left(\mathrm{kg} \mathrm{ha}^{-1}\right)\end{array}$} & \multicolumn{3}{|c|}{$\begin{array}{c}\text { Root nutrient removal } \\
\left(\mathrm{kg} \mathrm{ha}^{-1}\right)\end{array}$} \\
\hline $\begin{array}{c}\text { Irrigation } \\
\text { interval } \\
\text { (Days) }\end{array}$ & $\begin{array}{c}\text { Silicate } \\
\text { concentration } \\
\left(\mathbf{m g ~ L}^{-1}\right) \\
\end{array}$ & $\mathbf{N}$ & $\mathbf{P}$ & $\mathbf{K}$ & $\mathbf{N}$ & $\mathbf{P}$ & $\mathbf{K}$ \\
\hline \multirow{4}{*}{8} & 0 & $60.8 \mathrm{~cd}$ & $13.4 \mathrm{~cd}$ & $114.7 \mathrm{~cd}$ & $128.8 \mathrm{~cd}$ & $32.3 \mathrm{~cd}$ & $208.9 \mathrm{~cd}$ \\
\hline & 500 & $65.5 \mathrm{c}$ & $14.4 b c$ & $124.5 b c$ & $139.6 b c$ & $32.3 \mathrm{~cd}$ & $226.6 b c$ \\
\hline & 1000 & 73.3ab & $16.0 \mathrm{ab}$ & $139.7 \mathrm{a}$ & $155.7 \mathrm{a}$ & $35.0 \mathrm{bc}$ & $252.8 \mathrm{ab}$ \\
\hline & 2000 & $76.4 \mathrm{a}$ & $16.8 \mathrm{a}$ & $145.2 \mathrm{a}$ & $162.8 \mathrm{a}$ & $39.0 \mathrm{a}$ & $264.3 \mathrm{a}$ \\
\hline \multirow{4}{*}{14} & 0 & $54.9 \mathrm{~d}$ & $11.9 \mathrm{de}$ & $103.6 \mathrm{de}$ & $116.0 \mathrm{de}$ & $40.8 \mathrm{a}$ & $188.3 \mathrm{de}$ \\
\hline & 500 & $64.6 \mathrm{c}$ & $14.2 \mathrm{bc}$ & $122.6 b c$ & $128.4 \mathrm{~cd}$ & $29.0 \mathrm{de}$ & $223.1 b c$ \\
\hline & 1000 & $66.0 \mathrm{c}$ & $15.5 \mathrm{ab}$ & $134.2 \mathrm{ab}$ & $152.0 \mathrm{ab}$ & $34.4 \mathrm{c}$ & $244.2 \mathrm{ab}$ \\
\hline & 2000 & $67.4 b c$ & $14.3 b c$ & $148.5 \mathrm{a}$ & $155.2 \mathrm{a}$ & $38.2 \mathrm{ab}$ & $249.5 \mathrm{ab}$ \\
\hline \multirow{4}{*}{20} & 0 & $37.6 \mathrm{f}$ & $8.0 \mathrm{f}$ & $82.8 \mathrm{~g}$ & $86.8 \mathrm{~g}$ & $39.0 \mathrm{a}$ & $139.6 \mathrm{~g}$ \\
\hline & 500 & $43.8 \mathrm{ef}$ & $9.5 \mathrm{f}$ & $87.5 \mathrm{fg}$ & $96.6 \mathrm{fg}$ & $21.8 \mathrm{~g}$ & $155.3 \mathrm{fg}$ \\
\hline & 1000 & $44.4 \mathrm{ef}$ & $9.5 \mathrm{f}$ & $97.6 \mathrm{ef}$ & $102.0 \mathrm{ef}$ & $24.3 \mathrm{fg}$ & $164.0 \mathrm{ef}$ \\
\hline & 2000 & $47.3 \mathrm{e}$ & $10.1 \mathrm{ef}$ & $104.3 \mathrm{de}$ & $108.5 \mathrm{ef}$ & $25.7 \mathrm{ef}$ & $174.5 \mathrm{ef}$ \\
\hline
\end{tabular}

Means followed by the same letter are not significantly different within the same column at the 0.05 level of probability by Duncan's Multiple Range Test (DMRT).

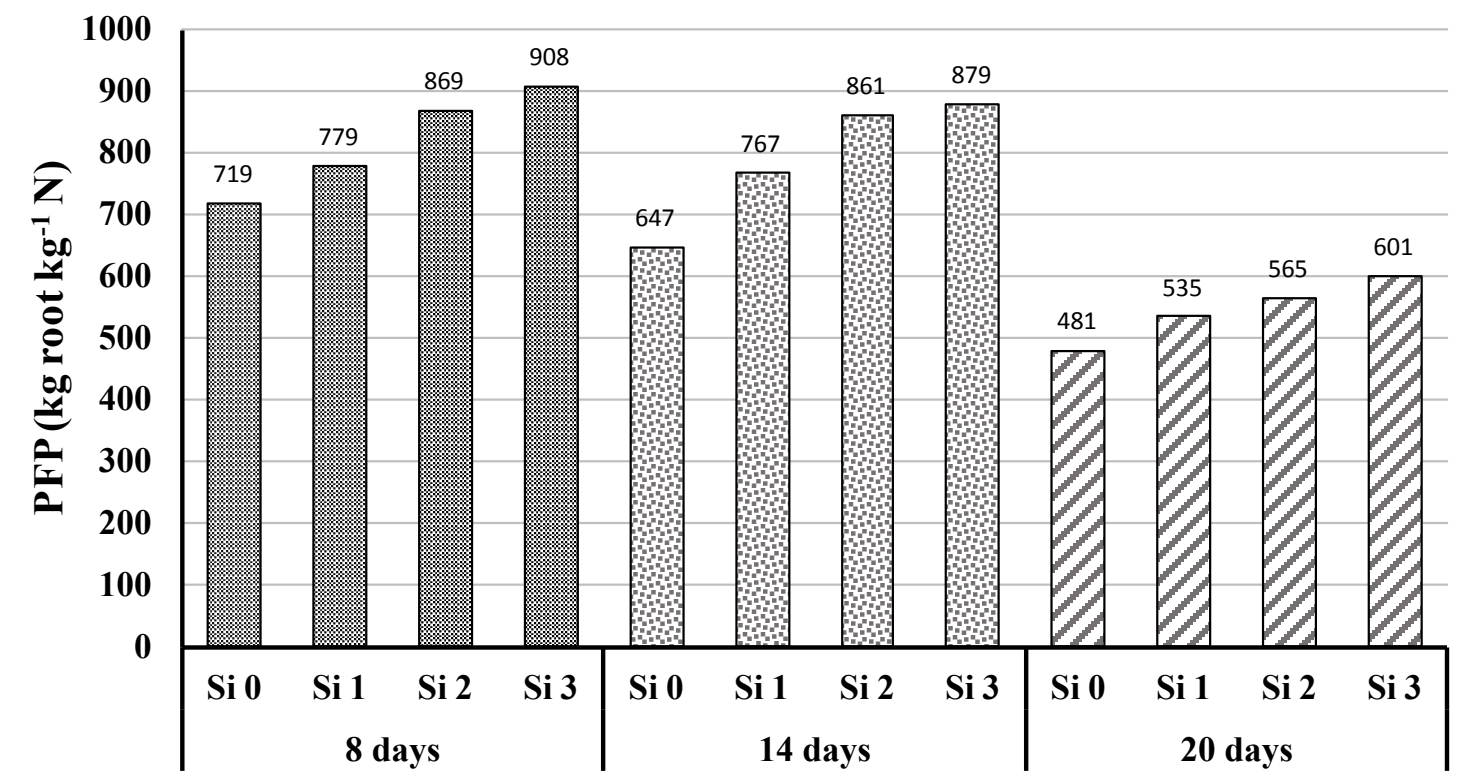

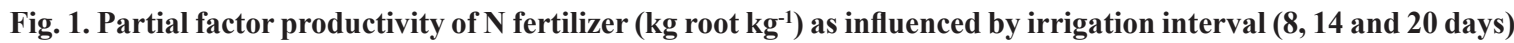
and spraying K-silicate at concentrations of 0 (Si 0), 500 (Si 1), 1000 (Si 2) and 2000 (Si 3) $\mathrm{mg} \mathrm{L}^{-1}$ silicate 


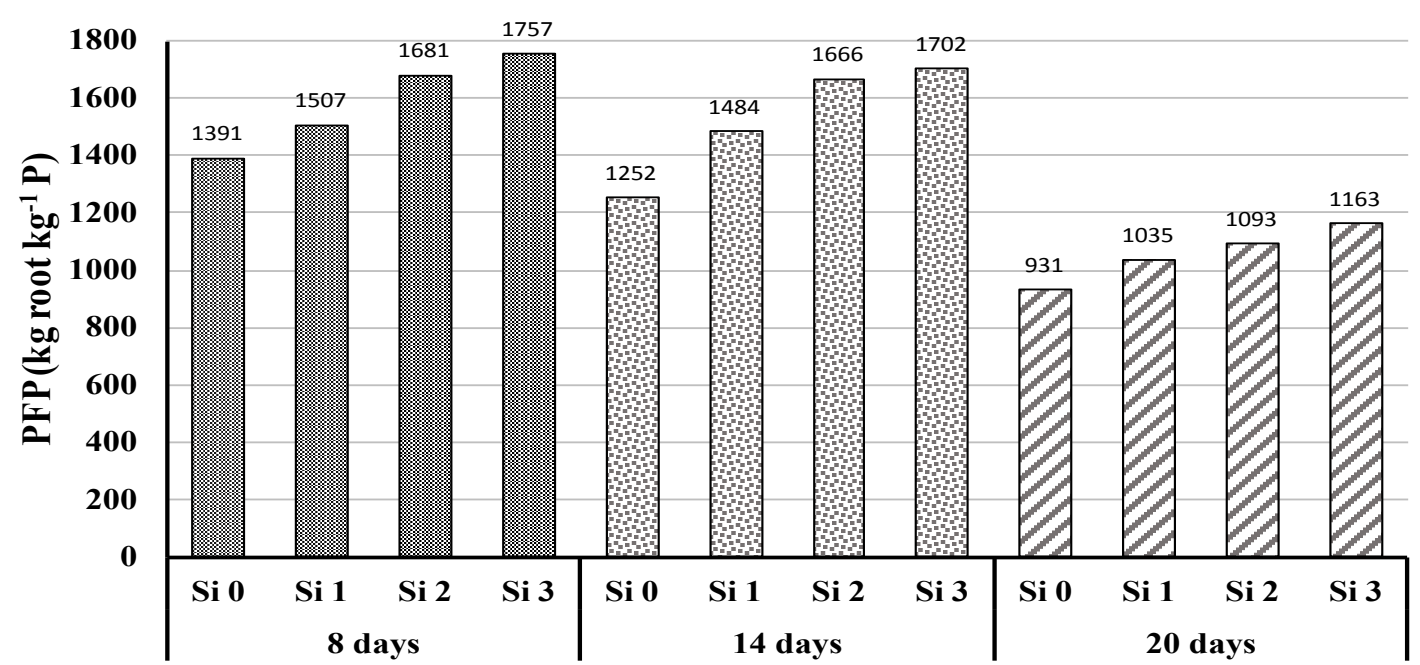

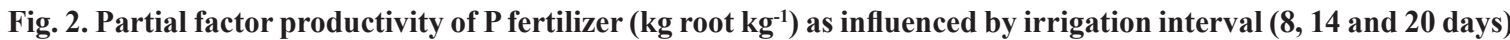
and spraying K-silicate at concentrations of 0 ( $\mathrm{Si} \mathrm{0),} 500$ (Si 1), 1000 (Si 2) and 2000 (Si 3) $\mathrm{mg} \mathrm{L}^{-1}$ silicate

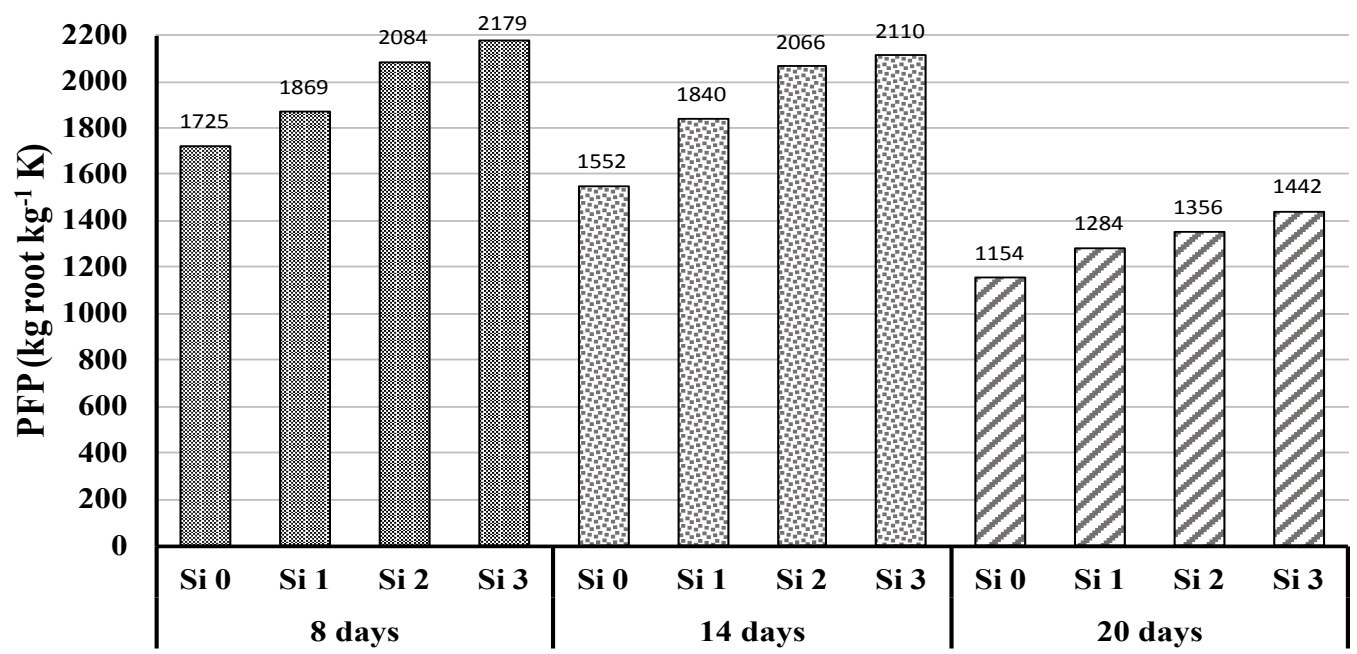

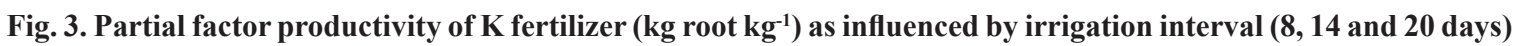
and spraying K-silicate at concentrations of 0 (Si 0), 500 (Si 1), 1000 (Si 2) and 2000 (Si 3) $\mathrm{mg} \mathrm{L}^{-1}$ silicate

\section{Conclusion}

Negative effects of drought stress on yield of sugar beet grown in calcareous soils could be alleviated by foliar spray of K-silicate. At moderate drought stress (irrigation every 14 days), spraying $\mathrm{K}$-silicate at a concentration of $1000 \mathrm{mg} \mathrm{L}^{-1}$ silicate could compensate the reduction in root yield by $33 \%$ on an average. Nutrient removal was also markedly improved with applying K-silicate. Fertilizer use efficiency, expressed as PFP, increased by spraying K-silicate, suggesting saving in fertilizer use by using this material.

\section{References}

Agarie, S., Agata, W., and Kaufman, P. B. (1998) Involvement of silicon in the senescence of rice leaves. Plant Prod. Sci., 1, 104-105.

Al-aghabary, K., Zhu, Z., and Shi, Q. (2005) Influence of silicon supply on chlorophyll content, chlorophyll fluorescence, and antioxidative enzyme activities in tomato plants under salt stress. J. Plant Nutr., 27, 2101-2115.

AOAC (1995) Association of Official Analytical Chemists. $16^{\text {th }}$ ed., Official Methods of Analysis, Washington, DC. 
Ashraf, M., Afzal, M., Ahmad, R., Maqsood, M. A., Shahzad, S. M., Aziz, A., and Akhtar, N. (2010) Silicon management for mitigating abiotic stress effects in plants. Plant Stress, 4, 104-114.

Ashraf, M., Ahmad, R., Afzal, M., Tahir, M. A., Kanwal, S., and Maqsood, M. A. (2009) Potassium and silicon improve yield and juice quality in sugarcane (Saccharumofficinarum L.) under salt stress. J. Agron. and Crop Sci., 195, 284-291.

Baligar, V. C., Fageria, N. K., and He, Z. L. (2001) Nutrient use efficiency in plants. Communications in Soil Science and Plant Analysis, 32, 921-950.

Blum, A. (1996) Crop responses to drought and the interpretation of adaptation. In: Drought Tolerance in Higher Plants: Genetical, Physiological and Molecular Biological Analysis (pp. 57-70). Springer, Dordrecht.

Cakmak, I. (2002) Plant nutrition research: Priorities to meet human needs for food in sustainable ways. Plant and Soil, 247, 3-24.

Dahnke, W.C., Johnson, G.V. (1990) Testing soils for available nitrogen, in R.L. Westerman, Ed., Soils Testing and Plant Analysis, 3rd ed., SSSA Book Series, Number 3, Soil Science Society of America, Madison, WI, USA.

Eneji, A. E., Inanaga, S., Muranaka, S., Li, J., Hattori, T., An, P., and Tsuji, W. (2008) Growth and nutrient use in four grasses under drought stress as mediated by silicon fertilizers. J. Plant Nutr., 31, 355-365.

Epstein, E., and Bloom, A.J. (2005). Mineral Nutrition of Plants: Principles and Perspectives. $2^{\text {nd }}$ ed. Sunderland (MA): Sinauer Associates, Sunderland, MA.

Gao, X., Zou, C., Wang, L., and Zhang, F. (2005) Silicon improves water use efficiency in maize plants. J. Plant Nutr., 27, 1457-1470.

Gomez, K. A., and Gomez, A. A. (1984) Statistical Procedures for Agricultural Research. John Wiley \& Sons.

Gong, H., Zhu, X., Chen, K., Wang, S., and Zhang, C. (2005) Silicon alleviates oxidative damage of wheat plants in pots under drought. Plant Sci., 169, 313-321.

Gunes, A., Inal, A., Bagci, E. G., and Pilbeam, D. J. (2007) Silicon-mediated changes of some physiological and enzymatic parameters symptomatic for oxidative stress in spinach and tomato grown in sodic-B toxic soil. Plant and Soil, 290, 103-114.
Gunes, A., Kadioglu, Y.K., Pilbeamm, D.J., Inal, A., Coban, S., and Aksu, A. (2008a) Influence of silicon on sunflower cultivars under drought stress, II: Essential and nonessential element uptake determined by polarized energy dispersive X-ray fluorescence. Communications in Soil Sci. and Plant Analysis 39, 1904-1927.

Gunes, A., Pilbeam, D.J., Inal, A., and Coban, S. (2008b) Influence of silicon on sunflower cultivars under drought stress. I: Growth, antioxidant mechanisms and lipid peroxidation. Commun. in Soil Sci. and Plant Analysis, 39, 1885-1903.

Hattori, T., Inanaga, S., Araki, H., An, P., Morita, S., Luxova, M., and Lux, A. (2005) Application of silicon enhanced drought tolerance in Sorghum bicolour. Physiol. Plantarum, 123, 459-466.

Ibrahim, H. I. M., Sallam, A. M., and Shaban, K. A. (2015) Impact of irrigation rates and potassium silicate fertilizer on seed production and quality of Fahl Egyptian clover and soil properties under saline conditions. Am.-Eurasian J. Agric. Environ. Sci, 15, 1245-1255.

Kalra, Y. editor. (1998) Handbook of Reference Methods for Plant Analysis. Boca Raton (FL): CRC Press.

Lawson, T., Oxborough, K., Morison, J. I., and Baker, N. R. (2003) The responses of guard and mesophyll cell photosynthesis to $\mathrm{CO}_{2}, \mathrm{O}_{2}$, light, and water stress in a range of species are similar. $J$. Experimental Botany, 54, 1743-1752.

Li, Q. F., Ma, C. C., and Ji, J. (2009) Effect of silicon on water metabolism in maize plants under drought stress. Acta Ecologica Sinica, 29, 4163-4168.

Liang, Y., Chen, Q. I. N., Liu, Q., Zhang, W., and Ding, R. (2003) Exogenous silicon (Si) increases antioxidant enzyme activity and reduces lipid peroxidation in roots of salt-stressed barley (Hordeum vulgare L.). J. Plant Physiol., 160, 1157-1164.

Liang, Y., Sun, W., Zhu, Y. G., and Christie, P. (2007) Mechanisms of silicon-mediated alleviation of abiotic stresses in higher plants: a review. Environ. Poll., 147, 422-428.

Ma, J. F. (2004) Role of silicon in enhancing the resistance of plants to biotic and abiotic stresses. Soil Sci. and Plant Nutr., 50, 11-18.

Ma, J.F., and Takahashi, E. (2002) Functions of Silicon in Plant Growth. In: Ma JF, Takahashi E. (Ed.) Soil, Fertilizer, and Plant Silicon Research in Japan, 1st ed. Amsterdam, the Netherlands: Elsevier Science. 
Maghsoudi, K., Emam, Y., and Ashraf, M. (2015) Influence of foliar application of silicon on chlorophyll fluorescence, photosynthetic pigments, and growth in water-stressed wheat cultivars differing in drought tolerance. Turkish $J$. Botany, 39, 625-634.

Marschner, H. P. (2011) Marschner>s Mineral Nutrition of Higher Plants. Academic press.

Page, A.L., Miller, R.H., and Keeney, D.R. (1982) Methods of Soil Analysis, Part 2, Chemical and Microbiological Properties, $2^{\text {nd }}$ ed., Agron. Series No 9, Am. Soc. Agron., Madison, WI.

Parveen N, and Ashraf M (2010) Role of silicon in mitigating the adverse effects of salt stress on growth and photosynthetic attributes of two maize (Zea mays L.) cultivars grown hydroponically. Pakistan J. Botany, 42, 1675-1684.

Raven, J.A. (2003) Cycling silicon: The role of accumulation in plants. New Phytologist, 158, 419430.

Romero-Aranda, M. R., Jurado, O., and Cuartero, J. (2006) Silicon alleviates the deleterious salt effect on tomato plant growth by improving plant water status. J. of Plant Physiology, 163, 847-855.

Sakamoto, T., and Murata, N. (2002) Regulation of the desaturation of fatty acids and its role in tolerance to cold and salt stress. Current Opinion in Microbiology, 5, 206-210.

Samarah, N., Mullen, R., and Cianzio, S. (2004) Size distribution and mineral nutrients of soybean seeds in response to drought stress. J. Plant Nutr., 27, 815-835.
Savant, N. K., Korndörfer, G. H., Datnoff, L. E., and Snyder, G. H. (1999) Silicon nutrition and sugarcane production: a review. J. Plant Nutr., 22, 1853-1903.

Shi, X., Zhang, C., Wang, H., and Zhang, F. (2005) Effect of $\mathrm{Si}$ on the distribution of $\mathrm{Cd}$ in rice seedlings. Plant and Soil, 272, 53-60.

Singh, K. K., Singh, K., and Singh, R. (2005) Effect of nitrogen and silicon levels on growth, yield attributes, and yield of rice in Alfisols. Inter. Rice Res. Notes, 30, 40-41.

Soltanpour, P.N. (1991) Determination of Nutrient Availability and Elemental Toxicity by AB-DTPA Soil Test and ICPS. In Advances in soil science (pp. 165-190). Springer New York.

Trenholm, L. E., Datnoff, L. E., and Nagata, R. T. (2004) Influence of silicon on drought and shade tolerance of St. Augustinegrass. Hort. Technology, 14, 487 490.

Yordanov, I., Vclikova, V., and Tsonev, T. (2003) Plant responses to drought and stress tolerance. Bulgarian J. Plant Physiology, Special Issue, 187-206.

Zhu, Z., Wei, G., Li, J., Qian, Q., and Yu, J. (2004) Silicon alleviates salt stress and increases antioxidant enzymes activity in leaves of saltstressed cucumber (Cucumis sativus L.). Plant Sci., 167, 527-533. 
تخفيف إجهاد نقص المياه بئِ اسطة الإضافة الورقية لسيليكات البوتاسيوم لبنجر السكر

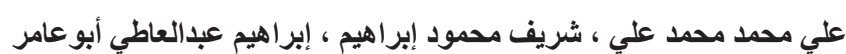

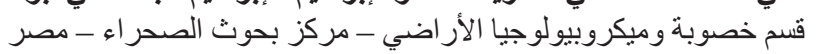

\begin{abstract}
يعتبر إجهاد الجفاف أحد أهم العوامل البيئية التي تحد من محصول وجودة العديد من المحاصيل النامية في

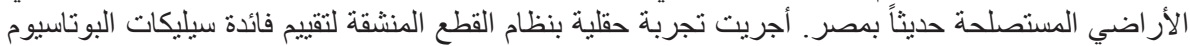

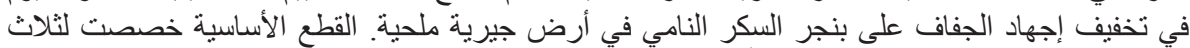

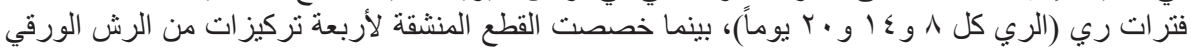

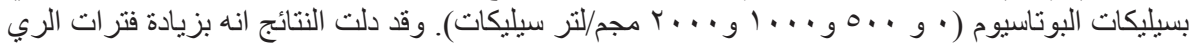

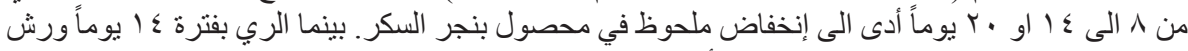

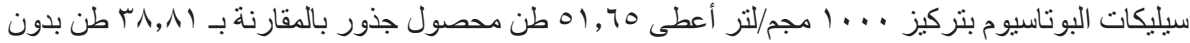

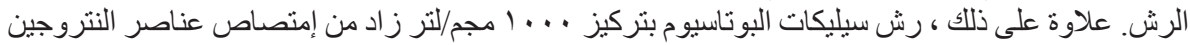

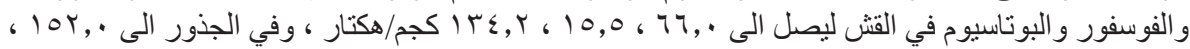

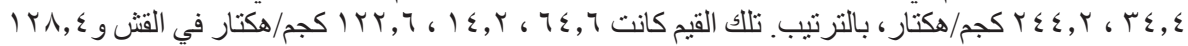

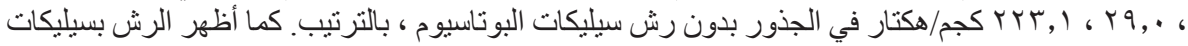

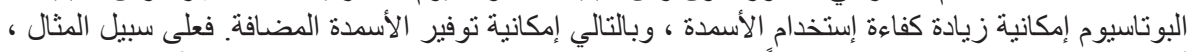

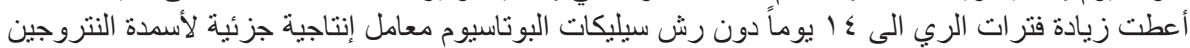

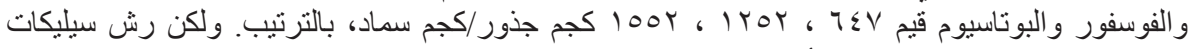

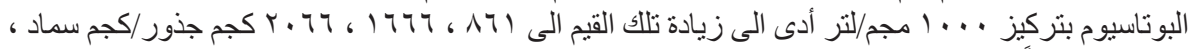

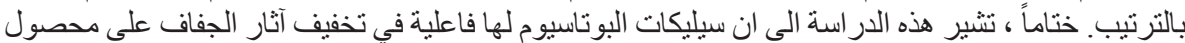

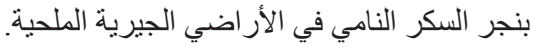

